\title{
Light on Creation
}

\section{Ancient Commentators in Dialogue and Debate on the Origin of the World Ed. by Geert Roskam and Joseph Verheyden}

[Die Schöpfung entdecken. Antike Kommentatoren in Dialog und Diskussion über den Ursprung der Welt.]

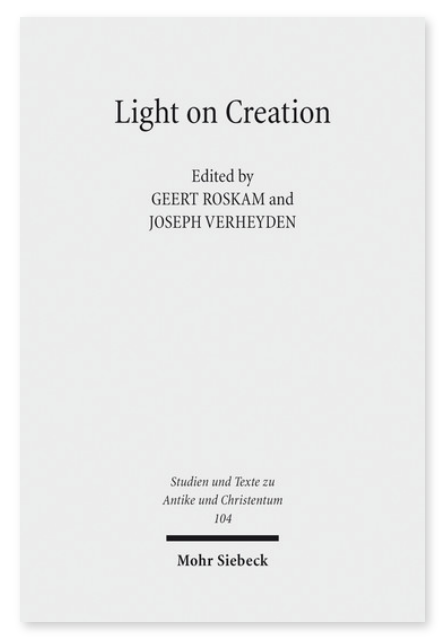

2017. X, 314 Seiten. STAC 104

ISBN 978-3-16-155586-2

DOI 10.1628/978-3-16-155586-2

eBook PDF $114,00 €$

ISBN 978-3-16-154314-2

fadengeheftete Broschur 114,00€
Veröffentlicht auf Englisch.

Der vorliegende Band enthält die Ergebnisse eines internationalen Kolloquiums, welches im Februar 2015 an der geisteswissenschaftlichen Fakultät der KU Leuven abgehalten wurden und Experten in (spät)antiker Philosophie und frühchristlichen Studien zusammenbrachte. Die Beiträger wurden gebeten, über die Rezeption zweier grundlegender Texte, die sich mit dem Ursprung der Welt befassen, zu reflektieren - dem dritten Buch von Platons Timaios und der Schöpfungsgeschichte aus Genesis. Die Organisatoren hatten zwei Ziele: Sie wollten ein Forum bieten, um den Dialog zwischen Kollegen aus diesen Fachgebieten voranzutreiben, indem sie aus vergleichender Perspektive sowohl ein entscheidendes Thema untersuchen, welches beide Traditionen teilen, als auch die literarischen Gattungen, durch die dieses Thema entwickelt und überliefert wurde.

\section{Inhaltsübersicht}

I. The Middle- and Neoplatonic Tradition

Mauro Bonazzi: Middle Platonists on the Eternity of the Universe - Sarah Klitenic Wear: The Position and Function of the Demiurge in Syrianus's Cosmos - Lorenzo Ferroni: Proclus, in Timaeum, II, 340.14-341.24 Diehl. Some Textual Remarks Gerd Van Riel: How Can the Perceptible World be Perceptible? Proclus on the Causes of Perceptibility

\section{The Christian Tradition}

David C. DeMarco: Basil of Caesarea's Exegesis of the Heavens in Homiliae in hexaemeron 3 - Volker Henning Drecoll: The Use of Scripture in Basil's Homilies in Hexaemeron - Samuel Pomeroy: Representing the Jews: John Chrysostom's Use of Exegetical and Theological Traditions for Gen 1:26a (In Gen. hom. 8) - David L. Dusenbury: Judaic Authority in Nemesius of Emesa's De natura hominis (390 CE) - Benjamin Gleede: Christian Apologetics or Confessional Polemics? Context and Motivation of Philoponus' De opificio mundi - Paul M. Blowers: From Nonbeing to Eternal Well-Being: Creation ex nihilo in the Cosmology and Soteriology of Maximus the Confessor - Clement Kuehn: Christ Hero. An Epic Commentary on Creation Dimitrios Zaganas: The Debate on Gen 1:1-3 According to Anastasius Sinaita's Hexaemeron

\section{Some Other Voices}

Gregory E. Sterling: »The Most Perfect Work«: The Role of Matter in Philo of Alexandria - Claudio Moreschini: Calcidius between Creatio Ex Nihilo and Platonism - Gerard P. Luttikhuizen: Gnostic Views on the Origin and the Nature of the Universe

Geert Roskam is Professor of Ancient Greek Literature in the Arts Faculty at the KU Leuven.

Joseph Verheyden is Professor of New Testament Studies in the Faculty of Theology and Religious Studies at the KU Leuven. https://orcid.org/0000-0002-8646-5233

Jetzt bestellen:

https://mohrsiebeck.com/buch/light-on-creation-9783161555862?no_cache=1

order@mohrsiebeck.com

Telefon: +49 (0)7071-923-17

Telefax: $+49(0) 7071-51104$ 